\title{
Critical Discourse Analysis of News Reports- Based on the Guardian News Report of China's Military Parade to Mark the 70 Years of Second World War
}

\author{
Xinling Tian \\ Chongqing Normal University, China
}

\begin{abstract}
Critical Discourse Analysis (abbreviated as CDA below), was firstly introduced by an English linguist, Norman Fairclough in the late 1980s. And CDA mainly focuses on public and non-literature discourse and it mainly applies Halliday's Systematic Functional Grammar (abbreviated as SFG below). Since China announced the decision of holding a military parade to celebrate the 70's anniversary of WWII victory, massive negative voices among the international society have been crowding in on China. Therefore, the present study was prompted to focus on the news report of China's military parade to celebrate the victory of WWII from the Guardian, and use Fairclough's Three-Dimensional Model of CDA as theoretical framework and apply Halliday's SFG as analytic tools to study two questions: How does the reporter insert his ideology in the news text of the Guardian news report on China's Military Parade to Mark the 70 Years of Second World War? What kinds of the social and historical ideologies bear in and account for the news? Through the analysis, it finds that Guardian's reports overemphasize and over interpret the negative influences of parade.
\end{abstract}

Index Terms — critical discourse analysis, news report, ideology, China's Military Parade

\section{INTRODUCTION}

\section{A. Research Background}

With the rapid economic development for several decades, every aspect of China, from micro social problems as well as every big move, has been drawing increasing attention from the world. "Media discourse is the main source of people's knowledge, attitudes and ideologies, both of elites as well as of ordinary citizens."(Van Dijk, 1993, P36). Hence, it is very important to study China's images in western medias and how ideology influences and bears in language.

China held a ceremonial military parade to celebrate the $70^{\text {th }}$ anniversary of the victory in the Chinese People's War of Resistance Against Japanese Aggression and the World Anti-Fascist War on Sep. $3^{\text {rd }} 2015$, which had attracted the world major medias' reports, however, the massive criticism outnumbered the positive messages of the parade and celebration. Seemingly, the rest of the world was hostilely over-interpreting this celebration. Negative comments and unpeaceful information were the main theme in multiples of world's media reports and editorials. However, to many ordinary Chinese, they felt excited, proud, and the old generation and veterans who were gone through that part of history were deeply touched and shed tears.

Apparently, the observers, commentators and reporters around the world had a difficulty in seeing eye to eye with even an ordinary Chinese on China's military parade to mark $70^{\text {th }}$ anniversary of the World War II. Even before the big event, many articles released online with analysis of the behind meaning in China's military parade were foreshadowing the enormous negative voices from the international community. The report on THE DIPLOMA was titled as China's Military Parade: A Warning to Japan and the US. Simultaneously, over the Pacific Ocean, CNN mainly focused on the comparison on global military force between China and the USA by citing table and pie chart from authority and institute, highlighting the lockdown in Beijing and the prohibition on entertainment broadcast. The Financial Times editorial displayed the attitude of criticism in the first paragraph; "China's rise as a regional hegemony and a blunt warning to the USA (Pomp, Circumstance and Combat Vehicles at Beijing Parade, The Financial Times)" and let alone the large quantities of critical quotations from the other observers and scholars in the article.

A report from Daily Mail, with the sentence "locals are banned from watching" in its news title prompted a hot discussion on Sina Weibo. Several comments and discussions with strong sentiments flowed in the blog. Many Chinese netizens showed drastic disapproval of the deliberate emphasis in this piece of news, arguing medias abroad reported this event with prejudices. One compatriot's comment on Daily Mail's message board evoked strong resonance among netizens on Sina Weibo.

B. Research Questions 
The year of 2015 meaningfully flagged the $70^{\text {th }}$ anniversary of the victory of the World War Second. As a member of the Allies and mainstay against Japanese Fascist in Asian battlefield in WWII, China held a celebration including activities of a reception, an evening gala and a military parade to celebrate the victory in the Chinese People's War of Resistance Against Japanese Aggression and the World Anti-Fascist War. For most Chinese, since it was a memorable and exciting event, they felt proud and strong ethos and all the reports and news covers were exactly the same way. However, English majors who utilize news reports to study English may encounter totally reversed reports, most of which were criticisms and negative information, totally different from what they had read from the domestic medias. Why medias abroad attacked China on such a big event on the victory day.

Based on this event and these phenomena, CDA and SFG will be conducted in this paper to investigate questions as follow:

(1)How does the reporter insert his ideology in the news text of the Guardian news report on China's Military Parade to Mark the 70 Years of Second World War?

(2)What kinds of the social and historical ideologies bear in and account for the news?

\section{LITERATURE REVIEW}

Since CDA is the basis of the whole study, firstly, a brief introduction will be drawn on CDA in this chapter. Then, Fairclough's Three-Dimensional Model and Halliday's Systemic-Functional Grammar serving as the theoretical framework and methodology of this paper will be detailed respectively. The literatures are surveyed to display the research and development on CDA from home and abroad in the following two parts. Afterwards, for CDA studies the abuse of power and hiding of ideology in language, the literature and research of ideology and power in language are reviewed to complete the theoretical basis of this thesis and then the connections between CDA and media discourse will be studied. At last the related CDA study on news reports with SFG was reviewed to show the hints of the present study.

\section{A. An Introduction of Critical Discourse Analysis}

As a newly-developing discourse analysis in the late of 1980s, CDA has been attracting an increasing attention of scholars from home and abroad. "Critical Linguistics" was firstly mentioned by Fowler in his book Language and Control published in 1979. Then ten years later, the term of Critical Discourse Analysis (CDA) was initially introduced by the English linguist, Norman Fairclough in his work Language and Power. "Critical Linguistics" is also called Critical Discourse Analysis. In China, majority of professors and scholars agree the standpoint that the two terms, CL and CDA refer to the same notion (Chen Zhonghua et al.,2002). In this dissertation, all the quotations and mentions of term CL are equally regarded as CDA.

Some Chinese representatives of this field define that CDA linguists disclose the complex relations among language, power, politics, social and historical ideology and decode how the injustice, inequality, political hegemony and ideological prejudice subconsciously spread through discourses mainly by studying the characteristics of discourses and the social and historical background of discourse.

\section{B. Fairclough's Three-dimensional Model}

Fairclough's Three-Dimensional Model has been a central theoretical framework for CDA linguists. As an interdisciplinary study, CDA highlights that the analysis of text can not be isolated from the discursive practice and the social context where it is produced.

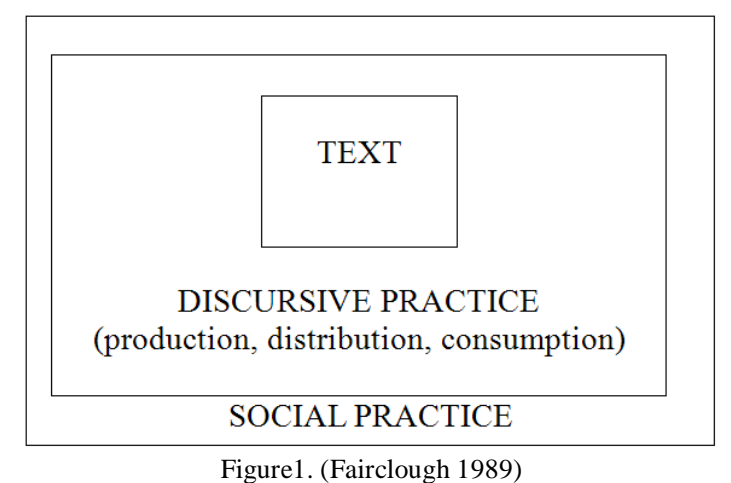

Fairclough illustrated the idea of discursive practice as a social practice within a diagram. It indicates: text is product of discursive practice or interaction process, and this practice includes the production and distribution and consumption of text, all which are all decided by condition of social practice (Xin Bin,2005). Early in 1989, Fairclough took the discourse as three dimensions: texts, interactions and contexts. Based on the three dimensions, he developed three stages or aspects of critical discourse analysis, description, interpretation and explanation:

(1)Description is the stage which is concerned with the formal properties of text, such as properties of vocabulary; 
textual structure.

(2)Interpretation is concerned with the relationship between text and interaction with seeing the text as a product of a process of production, and as a resource in the process of interpretation.

(3)Explanation is concerned with the relationship between interaction and social context, with the social determination of the process of production and interpretation and their social effect(Fairclough,Norman,1989).

The three dimensions could be illustrated in this following figure:

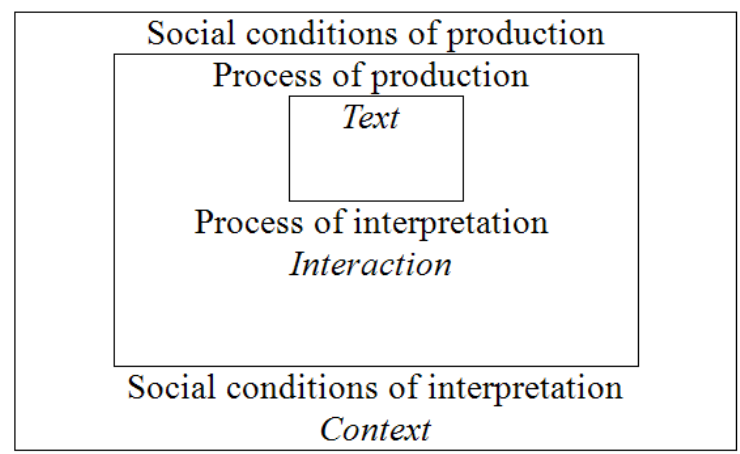

Figure2. Discourse as text, interaction and context (Fairclough,1992A)

We can understand the relationship between discourse and the three factors in the diagram as follow: firstly, it is the discourse as text of written and spoken language which contains formal properties like grammar and vocabulary. Secondly, it is discourse as discursive practice including the processes of production and interpretation of text, which means when analyze the language of text, the way discourse production and interpretation in society should be taken into consideration. The last one is discourse as social practice, which emphasizes that the analysis of language use in text and the processes of production and interpretation should be put into the corresponding social context.

Later in 1992, he combined the three conceptions of discourse with the three stages or aspects, and applied these aspects to in CDA of discourse.

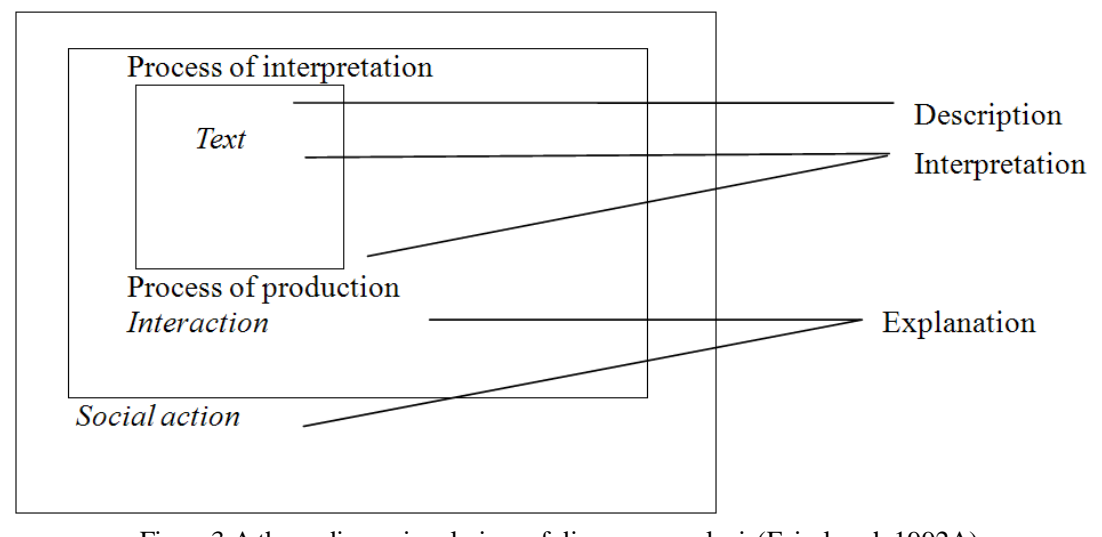

Figure3.A three-dimensional view of discourse analysis(Fairclough,1992A)

The conception of CDA and these three dimensions were explained in his book published in 1992. According to Xin Bin, that is to say "to describe formal properties of text, to interpret the relationship between text and interaction, and to explain the relationship between interaction and social context." (Xin Bin,2005,P55).

Fairclough noted "Each discursive event has three dimensions or facets: it is a spoken or written language text, it is an instance of discourse practice involving the production and interpretation of text, and it is a piece of social practice." (Fairclough,1993,P133). To sum up, when employing CDA into discourse, all the analysis of linguistic features, production and interpretation of text should be cast into its relevant context, because one of the main principle of CDA is that discourse is a social action.

\section{Halliday's Systemic-functional Grammar}

"CDA is regarded as an instrumental linguistics."(Folwer,R.1991,P481) According to Xin Bin, "CDA takes language as a muti-functional system" (Xin Bin,2005,P55), which shares the same ground with the Halliday's Systemic-Functional Grammar to regard language as a reflection of its function. Therefore, SFG constitutes the main methodology resource of CDA.

The unique form of language grammar system is closely related to the social and personal need of language (Halliday, 1971), which means that language must fulfill the three needs of its users. According to him, the three fundamental functions of language were proposed as follow in 1971: 
(1) ideational function which is "language serves for the expression of content... it is through this function that the speaker or writer embodies in language his experience of the phenomena of the real world; and this includes his experience of the internal world of his own consciousness: his reactions, cognition, and perceptions, and also his linguistic acts of speaking and understanding.

(2) interpersonal function which is the expression of his comments, his attitudes, and evaluation, and also the relationship that he sets up between himself and his listener-in particular the communication role that he adopts, of informing, questioning, greeting, persuading...

(3) textual function which is "in turn instrumental to these two, whereby language is, as it were, enable to meet the demands that are made on it...it is concerned with the creation of text...it is through this function that language makes links with itself and with the situations; and discourse becomes possible, because the speaker or writer can produce a text and the listener or reader can recognize one."(Halliday, 1971, P332-334).

Generally speaking, the ideational function is language's function as an expression of experience of the real world and the speaker's or writer's inner world; the interpersonal function is language's communicative function, which establishes, maintains and reflects the speaker's or writer's social relationships with others; the textual function is the function that the transfers of information and language compose a coherent and discursive text associated with its social and communicative context. Briefly speaking, language works as a construction of people's knowledge and thought system through the ideational function and forms social relationships between subjects by the interpersonal function. These metafunctions could be applied to explain the language intervention into society.

\section{CDA Studies Abroad and at Home and Related CDA Studies on News Reports from Transitivity System}

Affected by the "critical theory" in Western Marxism and in response to the long-dominant structural linguistics with representatives like Saussure and Bloomfield who regarded linguistic school as an abstractly self-contained and self-sufficient system, avoiding to cut off its connections to other disciplines like sociology, CL was conceived and laid the emphasis on one point that "disclose ideology hidden in the discourse text by analysis of society from language linguistics, application proper linguistic methodology and association with the historical and social background." (Chen Zhongzhu et al.1995, P21).

With such a critical trend, myriads of English linguists emerging focus on the non-literary discourse-public and media discourse in the late 1970s. "Critical Linguistics" was firstly mentioned by Fowler and some other linguists from the University of Anglia in the book Language and Control published in 1979 in which, they applied critical approach to analyze language in different discourse from news reports to regulations to study the interaction between ideology and discourse. Then after proposal of CDA for the first time in the book of Language and Power, Fairclough (1993) viewed discourse is use of language seen as a form of social practice. It is worthwhile noticing that the word "critical" in CDA carries no regular meaning of criticizing, picking flaws or complaining, instead "it aims to change or even remove what is considered to be a false or distorted consciousness and to render transparent what had previously been hidden. In so doing it initiates a process of self-reflection in individuals or in groups so as to achieve liberation from the domination of past constraints." (Connerton, 1976, P20).

Fairclough (1993) spilled out the purpose of the CDA by defining it as a discourse analysis which "aims to systematically explore often opaque relationships of causality and determination among discursive practices, events and texts, and wider social and cultural structures, relations and processes; to investigate how such practices, events and texts arise out of and are ideologically shaped by relations of power and struggles over power, and to explore how the opacity of these relationships between discourse and society itself as a factor secure power and hegemony." (Fairclough, 1993, P135).

The another prominent contribution of Fairclough(1993) lies in that he puts forward and applied the use three-dimensional framework to discourse analysis for the first time, which serves as a theoretical and methodological guide for CDA practitioners. He held a viewpoint that each discursive event has three dimensions or facets: it is a spoken or written language text, it is an instance of discourse practice involving the production and interpretation of text, and it is a piece of social practice.

The most recently literature from Van Dijk(1993) defined CDA as "a type of discourse analytical research that primarily studies the way social power abuse, dominance, and inequality are enacted, reproduced, and resisted by text and talk in the social and political context. With such dissident research, CDA analysts take explicit position, and thus want to understand, expose, and intimately resist social inequality." (Van Dijk, 1993, P374).

Comparing to the studies abroad, CDA in China needs catch up a little bit, starting with scholar Chen Zhongzhu in 1995. Due to the research blank, a growing number of domestic scholars have concentrated on the study of CDA. With the ardent research and arduous efforts, CDA studies in China had taken shape and deeply entered into a new course.

"The CDA development in China characterizes articles published in academic journalisms."(Ji Weining, 2006, P114). The articles could roughly be divided into four genres: (1) introduction of CDA theories (2) research on methodology of CDA (3) case study and application of CDA (4) interdisciplinary studies of CDA.

From the aspect of linguistics and philosophy, many Chinese scholars explained and illustrated the theories and methodology of CDA. The main ideas and methodology and the relationships among language, power, and ideology were generally introduced by Xin Bin (1996). Xin Bin (2005) concisely illustrated the methodology of CDA in English news, emphasizing to pay special attention to the social and ideological factors in its production, distribution, and 
interpretation.

The publication of Xin Bin's book (2005) helps to stretch the CDA studies in China to a new stage. In the book, he discussed language use in power and ideology and illustrated the methodology of CDA and application of CDA in news reports analysis. CL studies the relationships among language, power, ideology. It regards the text as the result of choice from the aspects of linguistic structure and ideology. And the most important theoretical basis and methodology come from the systematic functional grammar by Halliday (Xin Bin, 2005).

Under the theory of CDA, transitivity system in SFG is applied as methodology of present study, the studies of transitivity analysis of news reports will be survey in this session to display its effectiveness, and the methodology of present study will be explained in details in the following chapter.

On $4^{\text {th }}$ July of 1986, the local court in Birmingham declared the innocent verdict of the policeman who accidentally shot the suspect's five-year-old son in sleep to death in 1985. At that night, BBC news reviewed the death of the boy, "the boy died when the policeman's gun went off'. In the first place, BBC should have regarded this tragedy as a material process, reported it as other medias like "the policeman shot the boy" or "the boy was shot dead by the policeman"; however, BBC broke this event into two processes, avoiding the causal conjunctions such as because but using "when" to connect the two processes, therefore, the boy was no longer a victim but actor of the action "sleep"; the fact "the policeman shot" was downplaying as it was in the position of clause; the selection of verb "went off" turned the actor of action process into guns instead of the policeman(Xin Bin,2005). The selectivity in news reports can be realized through the choice of different processes, what's more, by investigating the linguistic features of these processes, the explicit and implicit ideology in news reports will be decoded, which hints a directions of present study.

\section{E. Power in Language and Ideology in Language}

Since CDA focuses on the language and ideology hidden in text, that is to say to study how use of language is applied to serve power order and power struggle in our society. Foucault used to say that "where there is discourse, there is power". CDA linguists deem discourse as a social practice, which means "first, the language is a part of society, and not somehow external to it. Secondly, that language is a social process. And thirdly, that language is a socially conditioned process, conditioned that is by other (non-linguistic) parts of society." (Fairclough, 1989, P22). Therefore, it decides that behind the discourse the whole social order of discourse composes together as a hidden effect of power (Fairclough, 1989). "Order of discourse refers to the specific texts in certain social field and institution, which composes and supports the social order." (Xin Bin, 2005, P31).

Fairclough used to criticize the conversational analysis, commenting that this kind of discourse analysis takes the control of power for granted. Hence, Fairclough(1992A) himself, thinks "the realization of controlling and the effectiveness of resistance depend on people developing a critical consciousness and its modalities, and challenging the mediator's positioning rather than just obeying it without questioning." (Fairclough,1992A,P8) That's what CDA pays attention to, language and ideology go hand in hand, and together they serve the power, building, consolidating and disorganizing the power system in our society.

The main task of CDA is to decode the associations among language, ideology and power. According to Chang Changfu (1998), ideology is "the ruling ideas of the ruling class, which puts emphasis on the relationships between acquired economic interests and the law, religion and philosophy which are shaped by it and serve it." (Chang Changfu, 1998, P229) "ideology essentially attempts to disguise the relations in reality, which is a reverse and mysterious reflection of the reality." (Yu Jingwu, 1993, P161). However, in the field of CDA, scholars hold a different view, and they regard ideology as a neutral concept. Fowler (1991) deems it as "the sum of ways in which people both live and represent to themselves their relationship to the conditions of their existence." (Fowler, 1991, P92). Kress and Hodge sees the ideology as a descriptive conception, viewing it as an ideological system organized from certain specific standpoint, which includes not only distorted political attitudes and theories but also science and metaphysics (Xin Bin, 2005).Thus, according to these reviews, ideology is something concealed and organized, so the informational formality of it could help to carry and spread ideology itself, which is what CDA tries to decode and reveal, the implicit ideology hidden in language.

\section{F. Media Discourse and CDA}

Thompson (1990) points out, that analysis of ideology in modern society must be sufficiently aware of the main functions of mass media's nature and effectiveness in the production and distribution of ideology. Since CDA was born, critical linguists have been attaching great importance on the analysis of the non-literal discourse. Media discourse, together with other mass discourse like advertisements and official fields consists of the analytical projects of CDA. So far, media discourse has been topping the list all the time. Media discourse, as an outcome of a social practice, news reports, like the other discourse, contain or demonstrate the reporters' viewpoints and stands. Therefore, there is no possibility that media discourse could absolutely objectively reflect and report the reality and society. As Geis has put forward, maybe the most significant right news media possesses is that it decides what question is important at what time and whose voice on what question should be reported (Xin Bin, 2005). That is to say media discourse and news reports is selective. Nowadays, mass media using English as a mediator has been penetrating every aspect of social life; "hegemony" sprouting from English and language culture has been becoming increasingly obvious; News reports in English dominate the world voice, even affect and control the public thought and awareness (Xin Bin,2005). For this 
reason, there is a need to apply CDA to news by analyzing the linguistic features, interpreting it from the social and historical background, to reveal the unaware ideology hidden in language; simultaneously, it helps to improve language awareness and critical thinking of readers.

\section{Methodology of Present Study}

\section{A. Methodology and Analytic Tools of Present Study}

Present study is mainly conducted by the application of Halliday's SFG as a methodology under the theoretical guidance of CDA and focuses on analyzing the linguistic features in the material, rational and verbal processes from transitivity system as the ideational function of discourse in the Gurdian's news report about China's WWII celebration and decoding the intertextuality of news by closely investigating the sources of these quotations. Hopefully, by analyzing the linguistic features from transitivity as an aspect of description, the production and interpretation of the news text and the explanation associated with social and historical background will be elucidated and the laden ideology within the news will be decoded. The answers would find all the proposed questions correspondingly.

\section{B. Transitivity}

"There are four aspects of English in discourse may contain ideology; they are the classification, transitivity, modality and transformation of discourse." (Xin Bin, 2005, P65). Halliday regarded the semanteme instead of the syntax as the basis of language to describe the real world, which means to study the ideational functions of different processes in text from the semantic system. Fairclough (1992B) defined transitivity as "the systemic linguistic term for exploring the ideational functional of grammar at the level of the clause." (Fairclough, 1992B, P177).

Halliday deemed that reality is made up of process, consisting of "goings-on": happening, doing, sensing, meaning, being and becoming. All of them are sorted out in the grammar of the clause which is the mode of action and reflection. The transitivity system construes the world of experience into a manageable set of process types: material process, mental process, relational process, behavioral process, verbal process and existential process. A process consists, in particular, of three components: the process itself, participants in the process and circumstance associated with the process. Those elements are expressed in the linguistic level as follow: processes by the verbal groups; participants by nominal group; and circumstances by adverbial groups or prepositional phrases.

\begin{tabular}{|l|l|l|l|l|}
\hline The mother & cooks & dinner & quickly & at home \\
\hline participant & process & participant & circumstance & circumstance \\
\hline nominal group & verbal group & nominal group & adverbial group & Prepositional phrase \\
\hline
\end{tabular}

Clause as process, participant and circumstance

"System of transitivity makes options available, and which process type is chosen to signify a real process may be of cultural, political or ideological significance" (Fairclough,1992B,P180), which means that selection of different type of processes and placement of participants and circumstances are closely associated the writters' or speakers' inclination, ideology and social and historical context.

\section{Processes of Transitivity in the Present Study}

\section{Material Process}

"Material process is the process of doing."(Halliday, 1994, P103). He explains the notion that some entities "do" something which may be done "to" some other entities. Material processes are not only physical events but also abstract doing or happening. The verb indicates the process, and the logical subject is named as "Actor" and the direct object is called "Goal"; similarly, the Actor and Goal may also be abstract entity or non-human. One point should be made clear that sometimes for certain language effects, the Actor may not be always appearing in the clause by employing passive voice. Thus, the emphasis of Goal will be achieved.

\begin{tabular}{|l|l|l|}
\hline the police (Actor) & shoot at (process) & the black man(Goal) \\
\hline the black man(Goal) & was shoot(process) & by the police(Actor) \\
\hline
\end{tabular}

\section{Relational Process}

Relational process is the process of "being", which intends to form a relationship between two participants without implying that one participant influence the other in any way. According to Halliday, there are two modes of relational process: attributive and identifying. Briefly speaking, attributive mode is that a participant has certain quality and in sentence this quality is an attribute, then the participant who carries this quality is called carrier. For example, James is knowledgeable. And identifying mode is identical properties of two entities; the identified and identifier refer to the same participants; for example Mary is teacher.

Another classification of relational process by Halliday is intensive ( $\mathrm{A}$ is a), circumstantial (A is in, at, under, for, with a), possessive (A has a). These two classification can be interflowing, seeing the following chart: 


\begin{tabular}{|l|l|l|l|}
\hline \multicolumn{1}{|c|}{ mode } & Intensive & Circumstantial & Possessive \\
\hline Attributive & Mark is smart & The book is on the table & The ring is Mary's \\
\hline Identifying & $\begin{array}{l}\text { Mike is the leader } \\
\text { The leader is Mike }\end{array}$ & $\begin{array}{l}\text { Tomorrow is V-DAY } \\
\text { V-day us tomorrow }\end{array}$ & $\begin{array}{l}\text { The book is mine } \\
\text { Mine is the book }\end{array}$ \\
\hline
\end{tabular}

The type of relational processes

3. Verbal Process

Verbal process is the process of "saying", within any symbolic exchange of meaning. It can be directly or indirectly quoted one. Three aspects of verbal process is namely, the participants: Sayer and Receiver, and the Verbiage. The verbiage is what is said or quoted.

\begin{tabular}{|l|l|l|l|}
\hline He (Sayer) & repeated (process:verbal) & the warning(Verbiage) & \\
\hline I(Sayer) & explained(process:verbal) & to her(Receiver) & what it meant(Verbiage) \\
\hline
\end{tabular}

\section{ANALYSis ANd Results of PrESENT StUdy}

\section{Data Collection}

Due to the limited length of the dissertation and in order to analyze the text effectively, this research did a little change about the Guardian's original news texts, which abandoned the instantly short pieces of live news on that day. All this omitted live news covered the information of parade and celebration rehearsal and the foreign dignitaries' reception and introduction of the dignitaries. Therefore, this dissertation mainly concentrated on the relatively long reports of this event, which comes into being the TEXT NO.1

1. Data Collection of Transitivity

The abbreviation of the six processes of transitivity is as follow:

\begin{tabular}{|l|l|}
\hline Full form & Abbreviation \\
\hline Material Process & MaP \\
\hline Verbal Process & VP \\
\hline Relational Process & RP \\
\hline Behavioral Process & BP \\
\hline Mental Process & MeP \\
\hline Existential Process & EP \\
\hline
\end{tabular}

"The transitivity system construes the world of experience into a manageable set of process types: material process, mental process, relational process, behavioral process, verbal process and existential process."(Halliday,1994,P107). During the production of news report, the orientation of reporter has an influence on the choice of process; reversely, the distinct choice of process will show a clue of the reporter's ideology.

The number and percentage of the six processes chosen by the reported are calculated as follow:

\begin{tabular}{|l|l|l|}
\hline & Number & Percentage \\
\hline $\mathrm{MaP}$ & 23 & 43.4 \\
\hline $\mathrm{RP}$ & 14 & 26.4 \\
\hline $\mathrm{VP}$ & 11 & 20.8 \\
\hline $\mathrm{MeP}$ & 4 & 7.5 \\
\hline $\mathrm{BP}$ & 0 & 0 \\
\hline $\mathrm{EP}$ & 1 & 1.9 \\
\hline Total & 53 & 100 \\
\hline
\end{tabular}

This data collection from the TEXT NO.1 calculated the verbs in simple sentence as well as those in main clauses in complex sentences. As for in compound sentences, all the verbs including in paralleled clauses are all also calculated among 748-word news text. Since the news text this dissertation studied contained the whole directed quotation report from AP, the verbs within the directed quotations as news, speech and editorials are also accounted in.

The frequency of different processes applied and the percentage in the text have been demonstrated in the chart. With the material processes, relational processes and verbal processes ranking orderly as the most frequently used processes in this news discourse, the linguistic features are relatively obvious. Since this piece of news report is about China's military parade to celebrate the WWII as the title of the news suggested, essentially speaking, it is a coverage of an event, therefore, there is no doubt that the material processes will top the list as the chart has shown. What's more, this also matches the nature of news as a kind of non-literal discourse to tell people what is happening around the world.

2. Material Processes Analysis of the News Report

However, if taken a close look at, the secrecy of application of the material processes will be disclosed. As the study has been explained above, material process is a process of doing, involved with Actor and Goal to explore the "doing" process. The total 23 material processes are presented in details: 


\begin{tabular}{|l|l|l|}
\hline lable & Actor or Agent & Action \\
\hline c & China military parade & Commemorates WWII Victory \\
\hline c & China & Has been working to squash negative views \\
\hline a & Xi & Needs to consolidate his power \\
\hline a & Xi & and take control \\
\hline a & He(Xi) & Wants to fan nationalistic \\
\hline b & Beijing residents & Not be given the opportunity \\
\hline b & Residents & Have received notices ordering \\
\hline c & Beijing & Moblised neighborhood watchers \\
\hline b & City roads & Will be closed \\
\hline b & Public bus service & Suspended \\
\hline b & Many bus stops & Sealed \\
\hline b & Cordon tape & Will keep members of public away from the parade \\
\hline c & Authorities & Are shutting \\
\hline b & Some buildings & Are staying shut for three days \\
\hline b & Nothing & Has been left to chance \\
\hline b & Many businesses and roads & Have been shut down \\
\hline b & Vehicles & Are allowed \\
\hline & The military & Have been deployed \\
\hline & China's role & Has been underplayed \\
\hline a & Xi Jinping & Used unusually strong language \\
\hline & Chinese people & Used their flesh and blood \\
\hline & A nation & Accustomed to concealing history and rejecting \\
\hline & Forum topics & Are banned \\
\hline
\end{tabular}

In the total of 23 material processes, there are four processes (labeled with $\mathrm{c}$ in the chart) referred to the government preparation of the celebration; four material processes were employed with $\mathrm{Xi}$ as Actor (labeled with a in the chart), which were from the quotations of the negative comments on $\mathrm{Xi}$. The Guardian should have reported this event itself but it actually focused on some secondary information about the government and comments on Xi. Thus the readers' concentrations will not be on the parade itself but leadingly on the criticism of the event. Since the reporter usually borrows other reports to showcase his own view, so in this dissertation, we take the quotation news from the AP as the reporter's own reports. When it came to the report the residential life around the parade area, and the preoccupations of the military parade, the reporter applied 10 material processes (labeled with $b$ in the chart) including 7 in passive voice, as "will not be given" "be shut down" "will be closed" "suspended" and "sealed" "have been shutting down" and "are allowed" to deliberately laid the emphasis on the orders issued by government and the inconvenience caused by the parade. The Actors of those material processes in passive voice are "most of Beijing residents, city road, public service, many subway stops, many business, vehicles", therefore the emphasis lays on the Actors, and the reporter conveyed an arbitrary and negative image of Chinese government to readers, which will easily prompt the censure from the discursive receivers. This is exactly the same as the report from Daily Mail. The material processes, which should have been chosen to demonstrate the reactions of the crowds in the parade spot, only amount to 3 in this articles; and material processes, which should have been applied to showcase the parades and the celebration conditions, were calculated none in this reports. The report entitled with China military parade commemorate second world war-as it happened lacks the description of the parade, the main commemorations of WWII and the reactions of the spectators but filled with the description of parade area life and preparation of parade from the negative perspectives. This kind of selectivity of report indicates that the reporter himself held a denial and negative attitude toward the military parade. The impression of China's extravaganza for big events and prejudice of socialist democracy have been long rooted in the western mind, thus when the journalist performed the discursive practice, he consciously concentrated on the negative and disapproval voice of the parade and understated that most Beijingers and compatriots were proud and excited of the parade despite the residential inconvenience and spot absence.

3. Relational Process Analysis of the News Report

As explained, the relational processes are the process of "being" categorizing into two genres: attributive process and identifying process. Attributive process is to describe certain qualities or properties the carrier possesses, and the identifying process is to identify the identified; that is to say, the two processes is to be understood as the carrier and the attribute, the identified and the identifier. Therefore, the relational process is a significant way to convey the reporter's opinion and judgment on certain events, which will also indicate his ideology and value-orientation. By analyzing the relational processes of this news, the Guardian reporter's attitude is obvious. 


\begin{tabular}{|l|l|l|}
\hline label & Carrier or Identified & Attributive or Identifier \\
\hline a & The parade & is typically blunt \\
\hline a & The parade & is to serve political needs \\
\hline a & The parade & is a good way of demonstrating \\
\hline a & The parade & is partly designed to flex \\
\hline a & The parade & is to consolidate Xi's political status \\
\hline c & Tiananmen Square & will be under curfew \\
\hline c & Today's massive parade & is a made-for-TV event \\
\hline a & The parade & is to redress the war narrative \\
\hline & The Japanese militarist invaders & were extremely bloody and cruel \\
\hline c & The anti-Japanese sentiment & is precisely why many major... \\
\hline b (a) & A great country and nation & has the courage to face up its history \\
\hline b (a) & To forget history & is to betray it \\
\hline b (a) & To deny a crime & is to repeat it \\
\hline b (a) & its future & will be like a tree without \\
\hline
\end{tabular}

The relational processes were calculated and the details were demonstrated in the chart. The total of relational processes was 14 , among which only 3 processes (labeled with $\mathrm{c}$ in the chart) were the reporter's description, and other 10 were the quotations from other's comments. As it is said, all the quotations in the news directly or indirectly represent the reporter's attitude and opinion. There are 6 processes (labeled with a in the chart) involved in the evaluation of the parade, among which 5 processes are from the quotations of criticism from Chinese historian. The secrecy of the relational processes lies in the quotations about history (labeled with $\mathrm{b}$ in the chart). Those historical views and evaluations were contained in Farris, the Beijing-based lawyers' criticism. Hence, these processes served as the same descriptive function as group a, and help to mount to the criticizing effects. Including those processes disguised as neutral historical views, the total relational processes in 64.3 percent consists into the negative evaluations of the parade and China. The reporter's ideology and attitude towards China is self-evident and obvious.

4. Verbal Process Analysis of the News Report

The verbal process is a process of "saying". Verbs such as say, report, talk, insist, claim, stress, pledge and add will indicate the verbal processes. The verbal process is involved with three factors: sayer, receiver and verbiage. When it comes to editorial comments about the parade, the ideational function was realized through the verbal processes.

\begin{tabular}{|c|c|c|c|c|}
\hline & Verb & Sayer & Receiver & Verbiage \\
\hline a & Says & Zhang(Chinese historian $)$ & Readers of this report & $\begin{array}{l}\text { "the parade is to.." } \\
\text { "Xi Jinping needs..." }\end{array}$ \\
\hline a & Believes & Zhang(Chinese historian ) & Readers of this report & $\begin{array}{l}\text { "wants to establish.." } \\
\text { "He wants to.." }\end{array}$ \\
\hline \multirow[t]{3}{*}{$\mathrm{a}$} & Adds & Zhang(Chinese historian ) & Readers of this report & "but the most of important ..." \\
\hline & Reports & $\mathrm{AP}$ and the Guardian & Readers of this report & Residents who live......three days \\
\hline & Reports & Fergus Ryan the reporter of the Guardian & Readers of this report & Today's........ \\
\hline $\mathrm{b}$ & Said & $\mathrm{Xi}$ & The world(speech) & "the Japanese ...to yield \\
\hline $\mathrm{b}$ & Added & $\mathrm{Xi}$ & The world(speech) & "in the face of...wall" \\
\hline $\mathrm{b}$ & Said & Genera Liu Yazhou & The public & "a nation accustomed to.." \\
\hline $\mathrm{b}$ & Maintain & China & The world & The parade is not aim \\
\hline $\mathrm{a}$ & Points out & William Farris & Readers of his blog & Forum topics about certain history events \\
\hline $\mathrm{a}$ & Quotes & William Farris & Readers of his blog & "A great..last long" \\
\hline
\end{tabular}

The whole verbal processes mainly serve as the description of the comments of the parade. The negative comments of parade mainly came from Chinese historian Zhang and lawyer William Farris, which represents the scholars from different fields of society; and the other four processes are mainly from China's official's view about history and Xi's speech about history. One of the purpose of massive media is to pursuit the truth of reality, in order to guarantee the authority and objectivity of report, most of the verbal processes are right from the insiders or authorities, carrying approval or disapproval attitude of the reporter meanwhile the reporter can borrow those quotations to express his ideology and standpoints. Although the reporter's disapproval sentiments towards China's parade are very clear in this report, but the production of this report is worth studying. To justify the criticism of the report, to convey the information that China's parade and celebration aimed at Japan, the reporter delicately arranged the criticism of China in the beginning and at end of the report, with quotations from Xi's speech and official's utterance about Japan and history in the middle. Following the reporter's train of thought, the readers will feel the criticism fair and reasonable and the reporter killed one bird with two stone. The responsibility for the views reported was subtly shunned and simultaneously, the criticism seemed legitimate and objective, and reasonably communicated to the receivers of the news.

The choice of verbs in verbal process can also indicate the reporters' attitude." China maintains the parade is not aim at ...". Unlike the other verbs, such as say, add and believe, the verb "maintain" is less neutral. It includes meaning of insisting and defending, which indicates the reporter is essentially disapproval of China's statement about the purpose of the parade. 


\section{CONCLUSION}

Through the analysis of material, relational and verbal processes in transitivity system, the reporter's description of the event and purpose of criticism were very clear. As for the descriptions of parade, the reporter focused on the editorials and preparations of the parade and underreported the parade itself and the reaction of audience. The reporter regarded the parade as a manifestation of the global most powerful military country, the consolidation of Xi's authoritarian leadership and reproachful and harsh attitude towards Japan on historical issues, which is overemphasized and exaggerated. However, the celebration of victory, commemoration of historical contribution and sacrifice and the peaceful rise and development were all shadowed under the domestic and overseas criticisms. Following the reporter's ideological instruction, it seems that the news report is objective and reasonable, however the long-existence ideology bears in the report and once more conveys to the potential readers.

With the rapid economic development, though it is slowing down now, China threat theory has been ingrained in the western. Every move of China will be deeply even over interpreted therefore the wary attitude towards China is utmost. Japan and the United States have a partnership in Asian-Pacific region. Japan is strategically in the same camp with the European. China's parade serves as a form of the celebrating activities to remind the world of what happened in the Eastern battlefield in the WWII. As a responsible power that played an extremely important role in the Asian battlefield to fight against Fascist Japan, China's sacrifice and contributions have been underreported compared with its counterparts who fight against Germany and Italy in Europe. This step and activities have difference in essence with Japan's concealing and denying of the war as a part of the world history, the historical revisionism. The western favoritism for Japan according to their national interests, because of the USA as the only superpower in the world, accounts for the criticism attitude towards China's parade. These are the social and historical ideologies rooted in the report and explaining for the production of the news text. The irreplaceable contribution and bleeding sacrifice of China, which should have been redressed on this celebration, were once more overwhelmed by the criticism due to the prejudice and bias rooted in the ideology.

As English majors, who are learning English through news, critical thinking and language sensitivity are necessity. We should equip with a critical thinking and identify those hidden ideologies in the news reporter and strength our language awareness, and keep a language sensitivity to judge all the information we are absorbing when learning English through media.

\section{APPENDIX (NEWS TEXT)}

\section{TEXT NO.1}

China military parade commemorates second world war victory-as it happened

\section{Last Updated: 08:36 GMT+8 Thursday, 03 September 2015}

\section{8:41}

China has been working very hard to quash negative views about today's commemorations but there are, of course, many who say the parade serves as propaganda for the regime.

Luna Lin, in the Guardian's Beijing bureau, has been talking to Zhang Lifan, a Chinese historian known for his outspoken criticism of the government. His reading of the parade is typically blunt.

"The parade is to serve political needs," Zhang says. "Xi Jinping needs to consolidate his power and to take control of the army after ousting senior military figures" in his anti-corruption drive.

Zhang believes China's president "wants to establish the image of being the most powerful leader since Mao Zedong and Deng Xiaoping. The parade is a good way of demonstrating his power and further strengthening his control of the army."

"He also wants to fan nationalistic sentiment among the public ... which is a common practice among authoritarian states."

The parade is partly designed to flex "China's muscles" on the international stage, Zhang adds. "But the most important of the parade is to consolidate Xi's political status and leadership."

\section{Last Updated: 08:41 GMT+8 Thursday, 03 September 2015}

\section{$08: 48$}

The Guardian's Tom Phillips is stationed in Tiananmen Square, along with a horde of journalists.

But most Beijing residents will not be given the opportunity to see the parade as it passes through their city.

As Associated Press reports:

Residents who live along the parade route have received notices ordering them to stay off balconies, keep windows shut, invite no guests and - at some buildings - snap no pictures.

"I am eager to watch the parade, but I understand it's impossible for everyone to have the chance to see it," said a Beijing lawyer who identified himself only by his surname, Yao. "I think watching the live broadcast will be a good alternative."

The neighborhoods around Tiananmen Square will be under curfew, and Beijing has mobilized 850,000 
neighborhood watchers to report anything even slightly out of the ordinary.

City roads will be closed, public bus service suspended and many subway stops sealed, while cordon tape will keep members of the public away from the parade. Authorities also are shutting down office buildings, shops, restaurants and even hospitals along the route for at least 24 hours. Some buildings are staying shut for three days.

Last Updated: 08:48 GMT+8 Thursday, 03 September 2015

09:10

My colleague Fergus Ryan reports from Beijing:

Today's massive parade is a made-for-TV event and nothing has been left to chance. Many businesses and roads have been shut down for the event. For the roads that are still open, around half of the cities' vehicles are allowed on them.

And the military has even deployed falcons and monkeys to prevent birds from getting in the way of the jets flying overhead.

One of the principal aims of this, the largest military parade in modern Chinese history, is to redress the imbalance China sees in second world war narratives. China's role in defeating Japan, in particular, has been underplayed, the argument goes.

At a medal ceremony for war veterans on Wednesday, president $X i$ Jinping used unusually strong language to describe the Japanese invaders, calling them "fiendish".

"The Japanese militarist invaders were extremely bloody and cruel, who treated the Chinese people with unprecedented brutality, and tried to use massacres and death to get the Chinese people to yield," Xi said, according to Xinhua news agency.

"In the face of the butchers' knives of the invaders, the Chinese people used their flesh and blood to build a new Great Wall," he added.

The anti-Japanese sentiment is precisely why many major leaders, including from from the UK, US, Australia and Japan, have shunned the event. Many western countries are reluctant to buy into Asia's "history wars".

Despite the rhetoric, China maintains that the parade is not aimed at today's Japan, but to remember the past and hope for peace.

In Wednesday's China Military Online, People's Liberation army General Liu Yazhou said of Japan: "A nation accustomed to concealing history and rejecting the truth ... has no hope."

But as Beijing-based lawyer William Farris points out in his blog Fei Chang Dao, forum topics online on Baidu for “the Cultural Revolution,” (文革) “The Great Leap Forward,” (大跃进) and “Tiananmen” (天安门) are banned.

Farris quotes a Global Times editorial entitled "Japan Must Face up to Verdict of History" by Sha Zukang, former UN under-secretary-general for Economic and Social Affairs: "A great country and nation has the courage to face up to its history. To forget history is to betray, and to deny a crime is to repeat it. Only by taking history as a mirror can Japan look into the future. Otherwise, its future will be like a tree without roots, which cannot last long."

Last Updated: 09:10 GMT+8 Thursday, 03 September 2015

\section{REFERENCES}

[1] Chang Changfu\&Gu Baotong. (1998). Contemporary Western Rhetoric. Beijing: China Social Sciences Publishing House.

[2] Chen Zhongzhu. (1995). Critical Linguistics Review, Foreign Language Teaching and Research, 1, 21-27.

[3] Cheng Zhonghua\&Yang Chunyuan\&Zhao Mingwei. (2002). Critical Discourse Analysis, Foreign Language Journal, 1, 82-86.

[4] Connerton,P. (ed.)(1976). Critical Sociology: Selected Readings. Harmondsworth: Penguin Books.

[5] Fairclough,.Norman.(1989). Language and Power. New York: Longman.

[6] Fairclough,.Norman. (1992A). Discourse and Social Change. Cambridge/Oxford: Polity Press.

[7] Fairclough,Norman.(ed.)(1992B). Critical Language Awareness. London/New York: Longman.

[8] Fairclough,Norman.(1993). Critical discourse analysis and the marketization of public discourse: Universities. Discourse and Society, 4 (2), 133-168.

[9] Fowler, R. (1987). Notes on critical linguistics. Steele \& T. Threadgold (eds.), Language Topics: Essays in honor of Michael Halliday. Amsterdam/Philadelphia: John Benjamins Publishing Company.

[10] Fowler, R. (1991). Language in the News: Discourse and ideology in the Press. London \& New York: Routledge.

[11] Geis, M. L. (1987). The Language of Politics. New York: Springer-Verlag.

[12] Halliday, M.A.K. (1971). Linguistic function and literary style: an enquiry into the language of William Golding's 'The Inheritors'. In Seymor Chatman (ed), Literary Style: a symposium. New York: Oxford University Press.

[13] Halliday, M.A.K. (1994). An Introduction to Functional Grammar. Beijing: Foreign Language Teaching and Research Press \& Edward Arnold.

[14] Ji Weining. (2006). Critical Discourse Analysis of Domestic and Foreign Development Profiles. Journal of Liaocheng University, 5, 113-114.

[15] Thompson, J. B. (1990). Ideology and Modern Culture. Cambridge: Polity Press.

[16] Van Dijk, T. A. (1993). Elite Discourse and Racism. Newbury Park, Calif: Sage Publications. Inc.

[17] Van Dijk, T.A. (2001). "Critical Discourse Analysis" in Tannen, D; Schiffrin, D. \&Hamilton, H. (eds.) Hand book of Discourse Analysis. Malden, MA\& Oxford,UK:Blackwell,352-371.

[18] Xin Bin. (1996). Language, Rights and Ideology: Critical Linguistics. Modern foreign language, 1, 21-26.

[19] Xin Bin. (2005). Critical Linguistics: Theory and Applications. Shanghai: Shanghai Foreign Language Education Press. 
[20] Yu Jinwu. (1993). Ideology. Shanghai: Shanghai People's Publishing House.

Xinling Tian was born in Fuling Chongqing in 1994. She is currently a postgraduate student in Chongqing Normal University. Her research interests include linguistics and cognitive linguistics.

Published paper: Cognitive Attributes of the Characteristics of Network Buzzwords----- Based on metaphorical cognition and metaphorical characteristics (Journal of Qiqihar Junior Teachers' College). 